\title{
COFFEE LEAF MINER INCIDENCE AND ITS PREDATION BY WASP IN COFFEE INTERCROPPED WITH RUBBER TREES
}

\author{
Humberto Godoy Androcioli' ${ }^{1}$, Adriano Thibes Hoshino², Ayres de Oliveira Menezes Júnior ${ }^{3}$, \\ Heverly Morais ${ }^{4}$, Rodolfo Bianco ${ }^{5}$, Paulo Henrique Caramori ${ }^{6}$
}

(Received: June 05, 2018; accepted: August 07, 2018)

\begin{abstract}
The coffee leaf miner (CLM) Leucoptera coffeella has a wide distribution and causes significant losses in coffee plantations (Coffea spp.) in Brazil. Its occurrence can be mitigated in intercropped systems, with the rubber tree (Hevea brasiliensis ) adapting well to the consortium, while also providing extra income to the producer. We aimed to determine whether the afforestation influences the microclimate and affects the leaf miner incidence and its predation by wasp in coffee plants intercropped with rubber trees. The study was undertaken in state of Paraná, Brazil, using coffee plants intercropped with rubber trees planted in double rows (alleys) spaced at 13,16 and $22 \mathrm{~m}$ between alleys, and compared to sole cropping coffee plots. From January 2008 to November 2010, the presence of CLM's lesions including those with signs of wasp predation was monitored in coffee plants intercropped with rubber trees and in the non-consorted coffee. A higher CLM's incidence was verified in monoculture coffee plots, while coffee plants located under and two meters away from rubber trees had the lowest incidences. CLM's incidence in intercropping system got higher as it increased distance from the trees. The number of lesions with signs of predation by wasps was positively correlated with the number CLM's lesions, indicating a density-dependent predator-prey relationship. The coffee plants intercropped with alley rubber trees reduce the CLM's occurrence and can be a management's tactic for this economically important pest.
\end{abstract}

Index terms: Coffea arabica, Leucoptera coffeella, Hevea brasiliensis, afforestation of coffee plants, shading.

\section{INCIDÊNCIA DE BICHO-MINEIRO E SUA PREDAÇÃO POR VESPAS EM CAFEEIRO CONSORCIADO COM SERINGUEIRA}

RESUMO: O bicho-mineiro do cafeeiro Leucoptera coffeella possui ampla distribuição e causa perdas significativas nas plantações de café (Coffea spp.) no Brasil. Sua ocorrência pode ser atenuada em sistemas consorciados, com a seringueira (Hevea brasiliensis) adaptando-se bem a consorciação, além de fornecer renda extra ao produtor. O trabalho objetivou determinar se a arborização influencia o microclima afetando a incidência do bicho-mineiro e sua predação por vespas em cafeeiro consorciado com seringueira. O estudo foi conduzido no estado do Paraná, Brasil, sobre plantas de café consorciadas com seringueiras plantadas em filas duplas (aleias) espaçadas a 13, 16 e $22 \mathrm{~m}$ entre aleias, e comparadas a parcelas de café em monocultivo. Entre janeiro de 2008 e novembro de 2010, a presença de lesões ocasionadas pelo bicho-mineiro, incluindo aquelas com sinal de predação por vespas, foi monitorada nas parcelas de café consociado com seringueira e nas parcelas de café em monocultivo. Maior incidência de bicho-mineiro foi verificada nos cafeeiros em monocultivo, enquanto plantas de café sob as seringueiras e a dois metros destas exibiram as menores incidências. A incidência do bicho-mineiro do cafeeiro no sistema consorciado foi maior com o aumento da distância das árvores de seringueira. O número de lesões com sinal de predação por vespas foi positivamente correlacionado com o número de lesões do bicho-mineiro, indicando uma relação predador-presa denso-dependente. Plantas de café, consorciado com seringueira em aléias, reduz a ocorrência do bicho-mineiro e pode ser uma tática de manejo para esta praga de importância econômica.

Termos para indexação: Coffea arabica, Leucoptera coffeella, Hevea brasiliensis, arborização dos cafezais, sombreamento.

\section{INTRODUCTION}

Coffee cultivation (Coffea spp.) plays an important role in the economy of Brazil, which is the world's largest producer and exporter, and the second largest consumer of the product (International Coffee Organization - ICO, 2018). Coffee plantations take up an estimated 2.16 million hectares distributed across 10 states, which correspond to $99 \%$ of the national production
(Companhia Nacional de Abastecimento CONAB, 2018).

Coffee plants in Brazil are predominantly cultivated in monocultures, due to the ease of managing and implementing mechanized cultivation techniques (CONCEIÇÃO; GUERREIRO-FILHO; GONÇALVES, 2005), which resulted in systems with greater spacings between the plants to accommodate the traffic of machines. However, greater spacings in monocrop

\footnotetext{
1,4,5,6Instituto Agronômico do Paraná/IAPAR - Rodovia Celso Garcia Cid, PR 445, km 375 - P.O. box 10.011 - 86.047-902 Londrina - PR - handrocioli@iapar.br, heverly@iapar.br, rbianco@iapar.br, caramori@iapar.br

${ }^{2,3}$ Universidade Estadual de Londrina/UEL - Rodovia Celso Garcia Cid, PR 445, Km 380 - Campus Universitário - Cx. P. 10.011 86.057-970 - Londrina - PR - hoshinoagro@gmail.com, ayres@uel.br
} 
coffee plantations expose the crop to climate risks such as frost, excessive solar radiation, and heat (WALLER; BIGGER; HILLOCKS, 2007). Moreover, plants spaced further apart are also vulnerable to wind and lower relative ambient humidity, factors that favor the incidence of the coffee leaf miner (CLM) Leucoptera coffeella (Guérin-Mèneville, 1842) (PARRA; REIS, 2013).

The CLM is the one of the main coffee pests in Brazil (CONCEIÇÃO; GUERREIROFILHO; GONÇALVES, 2005; PARRA; REIS, 2013). Its larvae consume the palisade parenchyma, causing: necrosis of the leaf blade, reduction of photosynthesis, and premature leaf fall (GRAVENA, 1983b; WALLER; BIGGER; HILLOCKS, 2007). One of the main control strategies has been the application of insecticides (CONCEIÇÃO; GUERREIRO-FILHO; GONÇALVES, 2005), but this solution results in a dependency on future insecticide use to manage the population level of the pest. In addition, intensive use of insecticides has caused problems, like insect resistance (FRAGOSO et al., 2002; RIBEIRO; MAGALHÂES; GUEDES, 2003).

In organic production systems the CLM can be mitigated by plant extracts (VENZON et al., 2005; ALVES et al., 2013), lime sulfur (VENZON et al., 2013), organic fertilization (THEODORO; GUIMARÃES; MENDES, 2014), and vegetational diversification with "key" plants (AMARAL et al., 2010). The crop diversification is desirable due to a sustainable pest control, based on system resilience (LIN, 2011).

The coffee crop diversification with other tree species is a promising alternative to reduce CLM's occurrence and make the management system less dependent on insecticide use. This is because coffee plants intercropped with tree species present lower insolation, air temperature, and wind intensity, as well as higher relative air humidity (CARAMORI et al., 2004; MORAIS et al., 2007), unfavorable conditions to the CLM's development (GUHARAY; MONTERROSO; STAVER, 2001; LOMELÍ-FLORES; BARRERA; BERNAL, 2010).

Natural enemies are more abundant in coffee systems intercropped with tree species resulting in reduced leaf miner populations (DE LA MORA; LIVINGSTON; PHILPOTT, 2008; REZENDE et al., 2014). Predatory wasps are considered the main agents of biological control for the CLM in Brazil, as they are responsible for the majority of leaf miner's mortality (TOZATTI; GRAVENA, 1988; PEREIRA et al., 2007). Intercropping with tree species has the potential to favor wasps by increasing shelter availability and nesting sites (SOUZA et al., 2014).
Rubber trees (Hevea brasiliensis Müell. Arg.) are a good choice for a producer to implement an intercropping coffee system. In addition of improving the microclimate for the coffee plants, rubber trees are well adapted to intercropped systems (RIGHI; BERNARDES, 2008), providing an alternative source of income (PEREIRA; PEREIRA; JUNQUEIRA, 1996). However, it's essential to understand how the proposed agroforestry intercropping will affect the main pest of the coffee plants. The simple diversification does not always reduce the pest occurrence (TSCHARNTKE et al., 2016). It was verified that coffee plants intercropped with banana trees (Musa spp.) or even the rubber trees (H. brasiliensis), in the tested design did not reduce the CLM occurrence (AMARAL et al., 2010; RIGHI et al., 2013). The selected tree's species or its spatial arrangement within intercropped systems, result in different microclimate changes (PARTELLI et al., 2014; ARAÚJO et al., 2015).

The coffee-rubber trees intercropped system in a design that decreases temperature and increases the humidity inside the system, as well as enhances the predatory wasp's establishment, probably will reduce the population densities of CLM. On the other hand, the trees can provide shelter to CLM's eggs and larvae against raindrop impacts, which cause great mortality (SILVA et al., 2003). This study aimed to determine whether the coffee intercropped with rubber trees at different densities, influences the microclimate (temperature, humidity and sun radiation) or provides protection against raindrop impacts, affecting the coffee leaf miner occurrence and its predation by wasps.

\section{MATERIAL AND METHODS}

The study was carried out from January 2008 to November 2010 in Londrina, Paraná state, Brazil $\left(23^{\circ} 21^{\prime} 38.22^{\prime \prime} \mathrm{S}, 51^{\circ} 10^{\prime} 04.15^{\prime \prime} \mathrm{W}\right.$, altitude $581 \mathrm{~m})$. The soil at the Experimental Station is Rhodic Ferralsol with a very clayey texture (Food and Agriculture Organization of the United Nations - FAO, 1997). The climate is humid subtropical (Cfa, according to the Köppen classification) with an average annual precipitation of $1,608 \mathrm{~mm}$ and average annual temperature of $21.1^{\circ} \mathrm{C}$ (Instituto Agronômico do Paraná - IAPAR, 2014). During the experimental period, records of cumulative monthly rainfall were obtained from a meteorological station located $100 \mathrm{~m}$ from the experimental plots. 
The experimental area consisted of coffee plants of the cultivar IAPAR 59, planted in the year 2000 in a $2.5 \times 1.0 \mathrm{~m}$ grid, with two plants per hole and rows arranged in a north-south direction. In the east-west direction, there were double rows (alleys) of rubber trees, Clone PB235, planted in 1999 with a spacing of $4 \mathrm{~m}$ between alley rows and $2.5 \mathrm{~m}$ between plants within the row (Figure 1).

This study used a randomized block splitplot design $(3 \times 5+1)$, with five repetitions. Each plot tested three different spacings $(13,16$, and $22 \mathrm{~m}$ ) between rubber tree alleys. For each alley spacing, coffee plants were sampled at five positions relative to the rubber tree alleys: between rubber trees within the alley (BRT), 2 $\mathrm{m}$ to the south and north of the alley $(2 \mathrm{~m}$ south and $2 \mathrm{~m}$ north), and in the middle between the focal alley and the next alley to the south (middle south) and to the north (middle north) $(6.5,8.0$, or $11.0 \mathrm{~m}$ from the focal alley, depending on alley spacing). All these designs were compared with coffee plants in the center of a monocrop system (Figure 1).

Coffee leaf miners were sampled on coffee plants in all intercropped and sole cropping systems. In each sampling point, intact leaf miner lesions and those with signs of predation by wasps were quantified using visual analysis of two pairs of leaves (third and fourth pair from the apex of the branch) on two branches (of upper half of plants) on eight plants, totaling 64 leaves on each evaluation. (a)

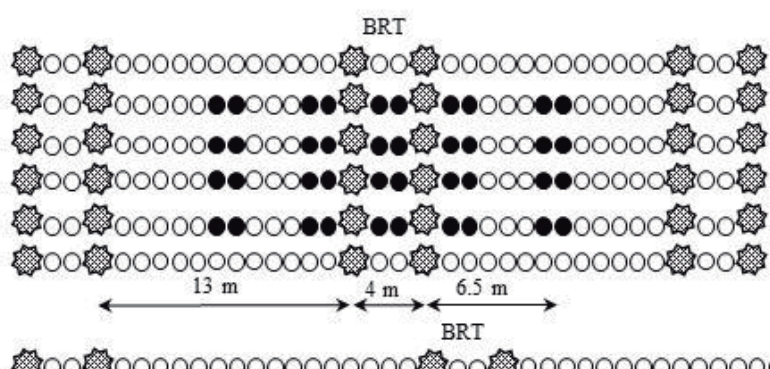

(b)

(c)
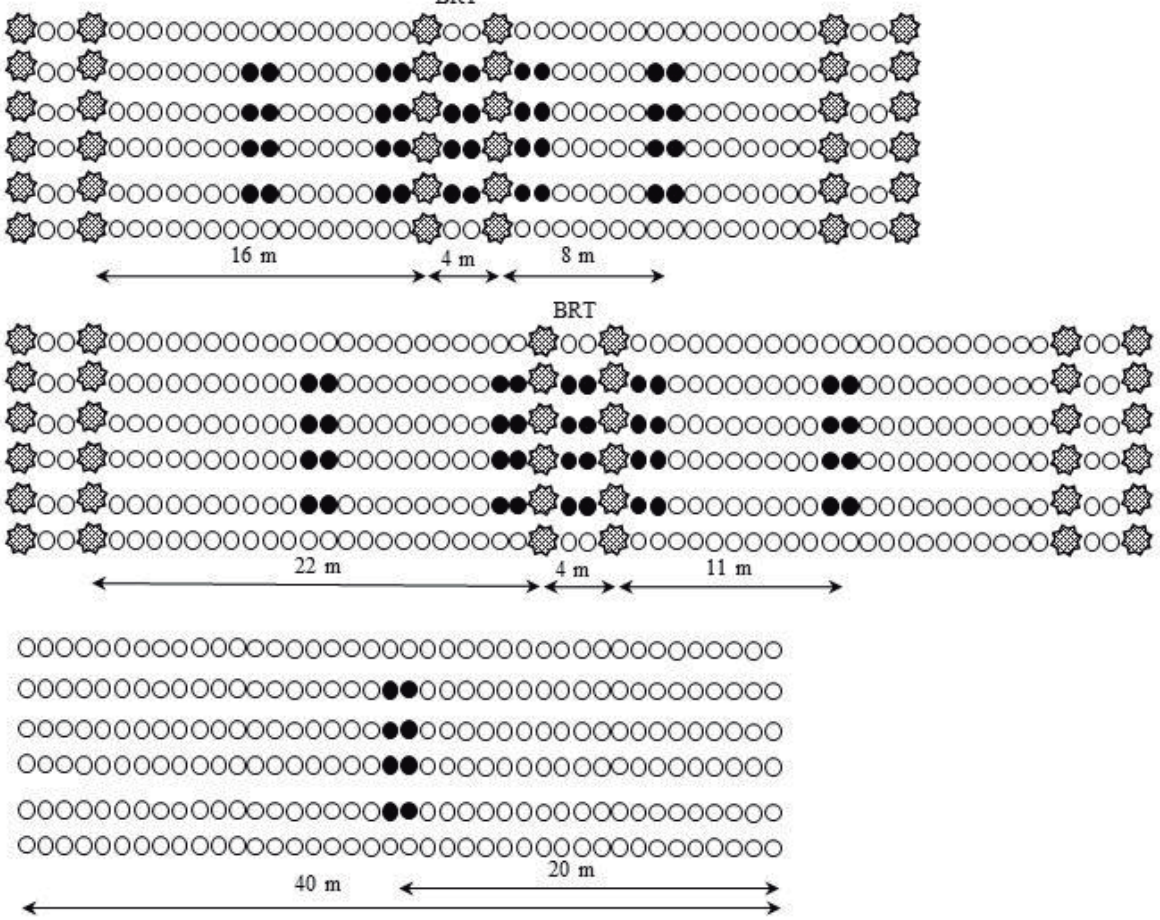

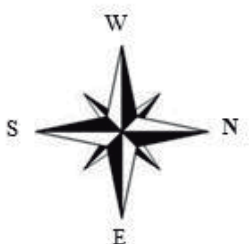

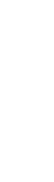


Over the study period, 35 monthly leaf miner evaluations were performed, giving a total of 2,240 leaves examined at each sampling point.

The following parameters were measured: number of coffee leaves with lesions produced by L. coffeella (percentage of leaves with at least one lesion), total number of lesions on the evaluated leaves (indicating the severity of the infestation), and total number of $L$. coffeella lesions with signs of predation by wasps.

In order to characterize microclimatic conditions, data on temperature and relative humidity were obtained from five automated meteorological stations installed at the following points in the experimental area: one in the center of the monocrop coffee plot, two $2 \mathrm{~m}$ away from the alley of rubber trees, and two in between the alleys spaced $16 \mathrm{~m}$ apart. The four meteorological stations in the intercropped plots were evenly distributed to the north and south of the alley. The sensors were installed at a height equivalent to the mean height of a coffee plant (approximately $85 \mathrm{~cm}$ above ground level). Data were obtained during the period April $16^{\text {th }}-19^{\text {th }}, 2010$. To better understand the results, data from the north and south sides were pooled and averaged for each distance in relation to the rubber tree alleys.

The rubber trees' shading over the coffee plants was estimated using illuminance (lux) measured with a digital lux meter. Readings were taken every half hour from sunrise to sunset on May $31^{\text {st }}, 2010$. These values were integrated over the day to determine the total daily illuminance and this value was used as a percentage relative to the value obtained in the monocrop coffee plots.

Before analysis, the data was tested for homoscedasticity and normality. In order to meet the assumptions for a parametric analysis, the data from the system intercropped with rubber trees were examined using variance analysis for subdivided plots and the outcomes for each configuration were compared using Tukey's test. Subsequently, the monoculture coffee plants were compared to those intercropped with rubber trees through a contrast analysis using the Scheffé test. For both tests, the significance threshold was 5\%. These statistical analyses were performed by using the statistical program SISVAR 5.3.

To examine the possibility of a densitydependent relationship between the pest and its predator, the association between the total number of $L$. coffeella lesions and the total number of lesions with signs of wasp predation was tested using Spearman's correlation analysis, using the statistical program BioEstat 5.0. Spearman's correlation analysis was also used to assess the association between leaf miner incidence (percentage of leaves with lesions and the total lesions on the third leaf pair) and monthly rainfall two months prior to the evaluation. Previous work has demonstrated that rainfall correlates with $L$. coffeella incidence in this time interval (ANTUNES, 1986), since the effects of rain on the incidence of lesions are become visible later.

\section{RESULTS AND DISCUSSION}

\section{Pest incidence and microclimates}

Coffee plants positioned between the rubber trees within the alley and at a distance of 2 $\mathrm{m}$ from them, showed lower $L$. coffeella incidence than coffee plants situated in between the alleys, both in terms of the number of leaves with lesions and the total number of lesions (Table 1 and 2). Moreover, the spacing between the rubber tree alleys influenced infestation intensity (number of leaves with lesions and total number of lesions) in the coffee plants positioned between the alleys. For coffee plants in this configuration, infestation was lower when rubber tree alleys were spaced at $13 \mathrm{~m}$ and greater when spaced at $22 \mathrm{~m}$ (Table 1 and 2).

The direction of the coffee plants from the rubber tree alleys did not influence the number of leaves with lesions or the total number of lesions, with similar results from plants on the south and north sides (Table 1 and 2). Regardless of the distance between the rubber tree alleys and the distance of the coffee plants to these alleys, all coffee plants intercropped with rubber trees showed a lower number of leaves with lesions and a lower total number of lesions compared to the monoculture coffee (Table 1 and 2).

The CLM's incidence was lowest in coffee plants within the alley and at $2 \mathrm{~m}$ of distance from it, and remained below the control level (30\% of leaves with lesions - see REIS; SOUZA; ZACARIAS, 2006) throughout the assessment period (Figure 2). The most intense infestation was found in the monoculture coffee plants followed by coffee plants situated between rubber tree alleys, with nine and six of the 35 monthly evaluations exceeding the control level, respectively. It is notable that when the percentage of leaves with lesions exceeded control levels, values for coffee plants in between alleys spaced $13 \mathrm{~m}$ apart remained close to $30 \%$; this was not the case for the other alley spacings (Figure 2). 
TABLE 1 - Percentage (mean \pm standard deviation; n=175) of leaves with Leucoptera coffeella (Guérin-Mèneville, 1842) lesions from coffee plants in different planting configurations, calculated across 35 monthly evaluations performed between January 2008 and November 2010. Londrina, PR.

\begin{tabular}{|c|c|c|c|}
\hline \multirow{2}{*}{$\begin{array}{l}\text { Position of } \\
\text { coffee plants }\end{array}$} & \multicolumn{3}{|c|}{ Spacing between rubber tree alleys $(\mathrm{m})$} \\
\hline & 13 & 16 & 22 \\
\hline$\overline{\mathrm{BRT}}$ & $4.0 \pm 1.0 \mathrm{Ba}^{*}$ & $4.2 \pm 0.5 \mathrm{Ba}^{*}$ & $4.8 \pm 0.8 \mathrm{Ba}^{*}$ \\
\hline $2 \mathrm{~m}$ south & $4.6 \pm 0.7 \mathrm{Ba}^{*}$ & $4.6 \pm 1.0 \mathrm{Ba}^{*}$ & $4.9 \pm 0.7 \mathrm{Ba}^{*}$ \\
\hline $2 \mathrm{~m}$ north & $4.3 \pm 0.5 \mathrm{Ba}^{*}$ & $4.5 \pm 1.0 \mathrm{Ba}^{*}$ & $4.3 \pm 0.6 \mathrm{Ba}^{*}$ \\
\hline Middle south & $11.9 \pm 0.9 \mathrm{Ab}^{*}$ & $13.4 \pm 1.3 \mathrm{Aa}^{*}$ & $14.4 \pm 0.9 \mathrm{Aa}^{*}$ \\
\hline Middle north & $10.7 \pm 1.1 \mathrm{Ac}^{*}$ & $12.5 \pm 1.3 \mathrm{Ab}^{*}$ & $13.9 \pm 0.9 \mathrm{Aa}^{*}$ \\
\hline Monocrop coffee & $18.4 \pm 0.8$ & & \\
\hline
\end{tabular}

TABLE 2 - Number (mean \pm standard deviation; n=5) of Leucoptera coffeella (Guérin-Mèneville, 1842) lesions across 2,240 leaves from coffee plants in different planting configurations, gathered from 35 monthly evaluations performed between January 2008 and November 2010. Londrina, PR.

\begin{tabular}{|c|c|c|c|}
\hline \multirow{2}{*}{$\begin{array}{l}\text { Position of } \\
\text { coffee plants }\end{array}$} & \multicolumn{3}{|c|}{ Spacing between rubber tree alleys $(\mathrm{m})$} \\
\hline & 13 & 16 & 22 \\
\hline BRT & $132.0 \pm 27.7 \mathrm{Ba}^{*}$ & $144.4 \pm 10.8 \mathrm{Ba}^{*}$ & $161.0 \pm 29.5 \mathrm{Ba}^{*}$ \\
\hline $2 \mathrm{~m}$ south & $150.2 \pm 20.9 \mathrm{Ba}^{*}$ & $153.0 \pm 37.6 \mathrm{Ba}^{*}$ & $165.2 \pm 27.2 \mathrm{Ba}^{*}$ \\
\hline $2 \mathrm{~m}$ north & $141.4 \pm 7.7 \quad \mathrm{Ba}^{*}$ & $157.2 \pm 30.4 \mathrm{Ba}^{*}$ & $143.4 \pm 25.5 \mathrm{Ba}^{*}$ \\
\hline Middle south & $375.8 \pm 46.1 \mathrm{Ac}^{*}$ & $421.0 \pm 28.4 \mathrm{Ab}^{*}$ & $470.6 \pm 49.4 \mathrm{Aa}^{*}$ \\
\hline Middle north & $334.2 \pm 37.6 \mathrm{Ac}^{*}$ & $412.4 \pm 30.0 \mathrm{Ab}^{*}$ & $465.2 \pm 27.8 \mathrm{Aa}^{*}$ \\
\hline Monocrop coffee & $646.8 \pm 39.7$ & & \\
\hline
\end{tabular}

The microclimate (temperature and relative air humidity) differed between monoculture coffee plants and intercropped ones with rubber trees. From 10:00 to 16:00, coffee plants located two meters from the rubber tree alley experienced lower air temperatures than the monoculture coffee plants and those in between the alleys 16 $\mathrm{m}$ apart, with greater differences in the hottest times of the day. In contrast, from 18:00 to 07:00, monoculture coffee plants experienced a slightly lower air temperature (Figure 3a). The relative air humidity demonstrated an opposite pattern compared to the temperature. From 10:00 to 16:00, relative humidity values for coffee plants
$2 \mathrm{~m}$ from the rubber tree alley were greater than for monoculture coffee, while from 18:00 to 07:00, humidity was higher for monoculture plants (Figure 3b). Coffee plants under the canopy of rubber trees thus experienced a lower range of temperature and relative air humidity than monoculture coffee plants.

The microclimate of forested systems is different to non-forested systems. The trees act as a windbreak and are a physical barrier to high insolation and water loss from evapotranspiration in the lower strata, resulting in greater humidity and lower air temperature in the hottest periods of the day (LIN, 2007, 2010). 


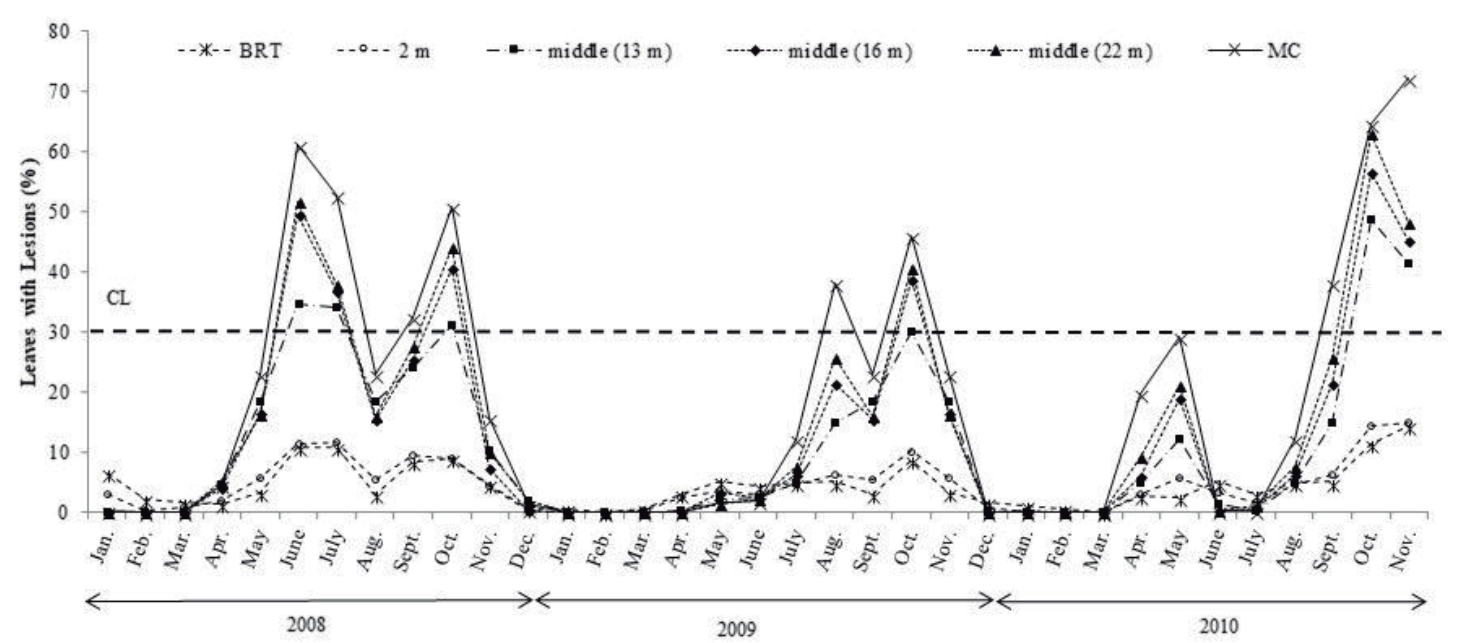

FIGURE 2 - Average percentage ( $\mathrm{n}=5$ replicates) of leaves with $L$. coffeella lesions in different planting configurations: monoculture coffee (MC), between rubber trees within an alley (BRT), $2 \mathrm{~m}$ away from the alley (2 $\mathrm{m}$ ), and in the middle between two alleys (middle) spaced 13, 16, or $22 \mathrm{~m}$ apart, during the years 2008 (a), 2009 (b) and 2010 (c). Horizontal dashed lines indicate the control level (CL) for L. coffeella, Londrina, PR.
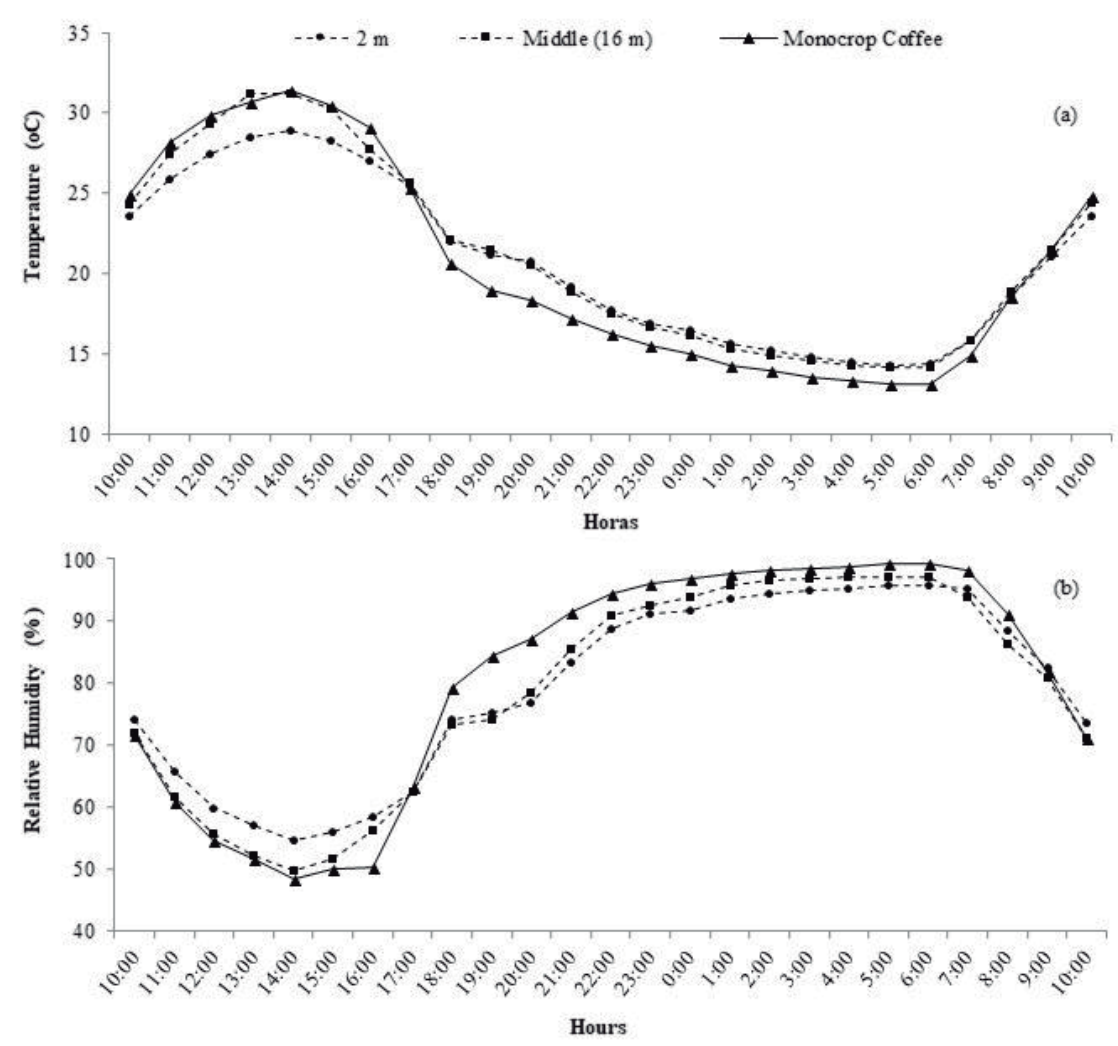

FIGURE 3 - Average values ( $\mathrm{n}=3$ days) for temperature (a) and relative air humidity (b) measured in three locations: in the center of the monoculture coffee plot, coffee plants $2 \mathrm{~m}$ away from rubber tree alleys and in the middle of two alleys spaced $16 \mathrm{~m}$ apart. Gray areas indicate the night period. Londrina, PR. 
These microclimate changes are likely to be linked to the lower incidence of $L$. coffeella in coffee plants near rubber trees. Studies indicate that a greater relative air humidity reduces the total number leaves with $L$. coffeella (GRAVENA, 1983a; GUHARAY; MONTERROSO; STAVER, 2001; TEODORO; KLEIN.; TSCHARNTKE, 2008). In addition, the decrease of temperature in the day's hottest periods, disfavor the CLM's incidence. Lomelí-Flores; Barrera; Bernal (2010) observed that the temperature influences not only the survival rate of L. coffeella, which is higher at higher maximum air temperatures, but also oviposition by leaf miner females, with no oviposition on nights with temperatures below $20^{\circ} \mathrm{C}$. Moreover, reduced temperatures increase the time required for the L. coffeella caterpillar-miners to hatch, as well as the duration of the caterpillar phase (PARRA; GONÇALVES; PRECETTI, 1981). This prolongs the biological cycle of the pest, reducing the number of generations per year and hence contributing to reduce the potential damage.

Overall, coffee plants situated under the rubber trees canopy had on average $61.6 \%$ shading (ranging $22.3 \%$ to $78.7 \%$ ), while those in between the rubber tree alleys had on average $29.5 \%$ shading (ranging $10.7 \%$ to $43.7 \%$ of shading) (Figure 4). The greater shading occurred in coffee plants situated on the south side of the alley $(70.8 \%$ to $78.7 \%)$.

This is probably due to the declination of the sun on the day when the measurements were taken due the latitude of the study site, thus the solar declination was slightly shifted to the north, resulting in a greater projection of shade towards the south side of the alley. Coffee plants beyond the rubber tree canopy showed the least shading $(10.7 \%$ to $20.1 \%)$ when rubber tree alleys were spaced furthest apart (22 m).

Coffee plants shaded by rubber tree alleys probably have higher water availability compared to coffee plants under direct sunlight farther away from the rubber trees. According to Neves et al. (2007), intercropping coffee plants in agroforestry systems entails water savings, and coffee transpiration has shown to be significantly reduced when it is grown in shade conditions (MORAIS et al., 2007). Righi et al. (2013) studying coffee in a crop production system with rubber trees, found a higher CLM's incidence after periods with greater soil water deficiency, the same occurred in the present study. Coffee plants under lower water stress are less susceptible to attacks from CLM (MEIRELES; CARVALHO; MORAES, 2001; ASSIS et al., 2012), given that plants under water stress show greater levels of nitrogen and lower levels of secondary metabolites, which are attractive to the pest (LAWTON; MCNEILL, 1979).

The shading provided by the rubber tree may also impair the CLM due leaf's anatomy alteration of coffee plants. The shading of the coffee leaves result in a thickening of the epidermal cells and a narrowing of the mesophyll cells (VOLTAN; FAHL; CARELLI, 1992). Thus, the caterpillar will cross the epidermis less readily and will have a smaller mesophyll area in which to develop, which may result in lower survival rates for leaf miners in the shaded areas.

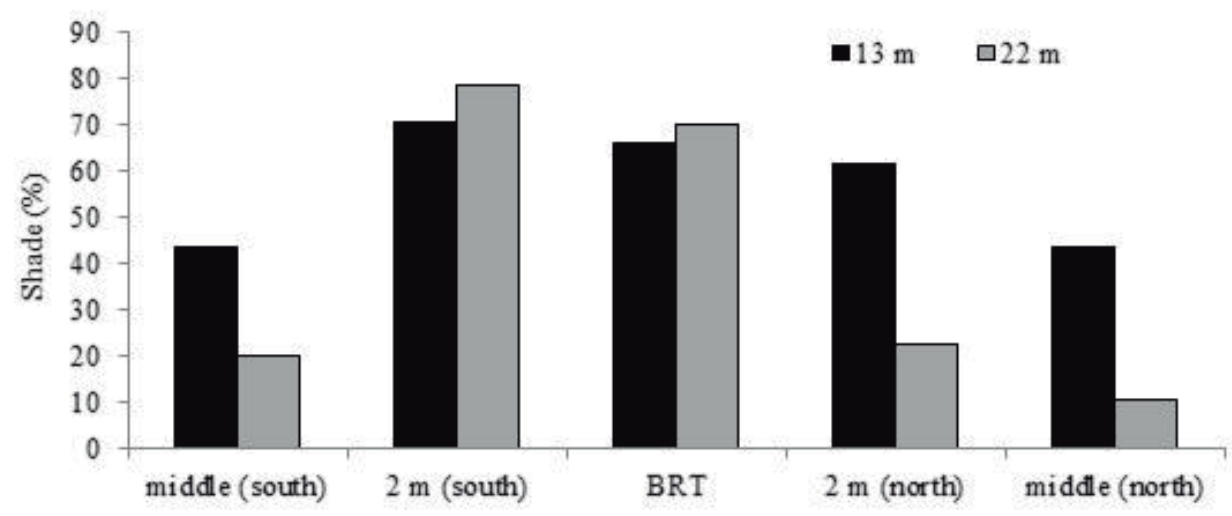

FIGURE 4 - Average values $(n=5)$ for percentage shading relative to monocrop coffee, at the top of coffee plants in different planting configurations: between rubber trees in the alley (BRT), two meters away from the alley ( $2 \mathrm{~m})$, and in the middle between two alleys (middle) spaced 13 or $22 \mathrm{~m}$ apart. Londrina, PR. 


\section{Predation by wasps}

The greatest predation of leaf miners occurred in the monoculture coffee plants. In an average of $646.8 \mathrm{~L}$. coffeella lesions present in this system (Table 2), approximately 111.6 (17.3\%) presented signs of wasp predation. In the system intercropped with rubber trees, coffee plants situated within the rubber alley and $2 \mathrm{~m}$ away from it showed fewer lesions with signs of wasp predation (from 22.2 to 33.4 ) than the coffee plants in between alleys (from 42.0 to 59.8). In addition, for coffee plants in between two rubber alleys on the north side, the number of lesions with signs of predation was lower when the alleys were spaced $13 \mathrm{~m}$ apart compared to $22 \mathrm{~m}$ apart (Table 3 ).

There was a strong positive correlation ( $\mathrm{r}$ $=0.80 ; p<0.01$ ) between number of lesions and the number of lesions with signs of predation, increasing the number of lesions with signs of wasp predation proportional to the incidence of lesions in the different locations, suggesting a densitydependent effect between pest and predator.

Predatory wasps are an important natural enemy in Brazilian coffee plantations, being the main biotic cause of CLM's mortality (PEREIRA et al., 2007). More leaf miner predation was expected in the coffee plants intercropped with rubber trees, since greater numbers of natural enemies are supported when the plant diversity in an agricultural system is greater, resulting in improved biological control of pest (BIANCHI; BOOIJ; TSCHARNTKE, 2006). Moreover, studies indicate that the predatory wasps prefer arboreal plants to set nesting sites (SANTOS; BISPO; AGUIAR, 2009; SOUZA et al., 2014), favoring its permanence in arborized systems.
However, the greatest number of predated mines occurred in the monoculture coffee plants, followed by coffee plants in between two rubber tree alleys, which also showed greater incidence of the leaf miner. The results observed in our study are probably due to the experiment's size and design. Several studies indicate that the main predator wasps' species of the leaf miner that occur in the coffee plants are Polistes spp., Polybia spp., Protonectarina sylveirae (de Saussure, 1854), and Brachygastra spp. (GRAVENA, 1983a; TOZATTI; GRAVENA, 1988; PEREIRA et al., 2007; SCALON et al., 2011), where the genera Polybia spp. and Polistes spp. has been shown to have a foraging range of $75-126 \mathrm{~m}$ from its nest (BICHARA FILHO et al., 2010; PREZOTO; GOBBI, 2005; SANTOS et al., 2000). In this study, however, the maximum distance between a double row of rubber trees and the center of the locations considered sole cropped was approximately $20 \mathrm{~m}$ (Figure 1), such that there were no coffee plants at a distance greater than the wasps' dispersion capacity. Thus, in terms of wasp foraging behavior, the experiment as a whole probably functioned as a large intercropped system.

In a situation in which there are no environmental limits on the wasps' dispersal ability, they are expected to forage preferentially in locations with greater prey availability, due the wasps' capacity to memorize sites where they had greater success in capturing food (RICHTER, 2000), minimizing energy expenditure when searching for food.

TABLE 3 - Number (mean \pm standard deviation; $n=5$ ) of Leucoptera coffeella (Guérin-Mèneville, 1842) lesions with signs of wasp predation across 2,240 leaves from coffee plants in different planting configurations, gathered from 35 monthly evaluations performed between January 2008 and November 2010. Londrina, PR.

\begin{tabular}{lccc}
\hline \multirow{2}{*}{$\begin{array}{l}\text { Position of } \\
\text { coffee plants }\end{array}$} & \multicolumn{3}{c}{ Spacing between rubber tree alleys $(\mathrm{m})$} \\
\cline { 2 - 4 } & 13 & 16 & 22 \\
\hline BRT & $25.0 \pm 6.6 \mathrm{Ba}^{*}$ & $26.8 \pm 4.1 \mathrm{Ba}^{*}$ & $33.4 \pm 11.8 \mathrm{Ba}^{*}$ \\
2 m south & $26.2 \pm 4.2 \mathrm{Ba}^{*}$ & $26.2 \pm 5.2 \mathrm{Ba}^{*}$ & $22.2 \pm 6.1 \mathrm{Ba}^{*}$ \\
2 m north & $27.0 \pm 6.9 \mathrm{Ba}^{*}$ & $22.8 \pm 10.9 \mathrm{Ba}^{*}$ & $25.0 \pm 13.1 \mathrm{Ba}^{*}$ \\
Middle south & $42.6 \pm 7.1 \mathrm{Aa}^{*}$ & $42.2 \pm 9.9 \mathrm{Aa}^{*}$ & $55.2 \pm 16.2 \mathrm{Aa}^{*}$ \\
Middle north & $42.0 \pm 5.8 \mathrm{Ab}^{*}$ & $50.4 \pm 8.8 \mathrm{Aab}^{*}$ & $59.8 \pm 7.3 \mathrm{Aa}^{*}$ \\
\hline
\end{tabular}

Monocrop coffee $111.6 \pm 12.0$

(a) Between rubber trees within an alley (BRT), $2 \mathrm{~m}$ away from the alley (2 m), and in the middle between two alleys (Middle). Values followed by the same letter did not differ significantly (Tukey test, $\alpha=5$ ); the upper-case letter denotes column values and the lower-case line values. The * indicates a significant difference (Scheffé test, $\alpha=5$ ) compared with sole cropping coffee. 
The strong positive correlation between the number of predated mines by wasps and the total number of mines in the leaves indicate a densitydependent relationship between predators and prey, corroborating that which has been previously noted between predatory wasps and $L$. coffeella by Fernandes et al. (2009).

\section{Effect of rainfall on pest incidence}

Rainfall correlated moderately and negatively with the percentage of leaves with lesions $(-0.38 \leq \mathrm{r} \leq-0.55 ; p \leq 0.03)$ and with the total number of lesions $(-0.41 \leq \mathrm{r} \leq-0.54 ; p \leq 0.02)$ at the different sampling points. To the coffee plants beneath rubber tree canopy the negative correlation ranged between -0.38 and -0.55 , while in the monoculture coffee system ranged between -0.44 and -0.42 . Thus, the increase in rainfall resulted in the lower number of lesions in the leaves, irrespective of the system of cultivation (monocrop or intercropped with rubber trees) or the distance of the coffee plants from the rubber trees.

The incidence of $L$. coffeella decreased as the rainfall increased, corroborating other studies that have shown a reduction in the leaf miner's survival rate during rainy periods (ANTUNES, 1986; LOMELI-FLORES; BARRERA; BERNAL, 2010; RIGHI et al., 2013). Pereira et al. (2007) found that rainfall is one of the primary causes of mortality at the egg and especially larval stages, which occur during the rainy season. Other authors suggest that larval mortality during rainy periods occur because the larvae drown in flooded lesions (NESTEL; DICKSCHEN; ALTIERI, 1994; VEGA; POSADA; INFANTE, 2007).

Coffee plants beneath rubber tree canopy would be protected from rain drops impact and thus avoid larvae drown in flooded lesions, however this was not observed in this study, due to the correlations between leaf miner incidence and rainfall were similar between coffee plants beneath rubber trees and monoculture coffee plants. Probably the alley intercrop system does not provide shelter to the leaf miner against rain impact, since the study area have convective summer rainfall (strong winds with oblique rainfall) (GRIMM, 2009) reaching coffee plants within the rubber alley.

The results indicate that the adoption of coffee intercropped with higher rubber tree densities (13 $\mathrm{m}$ between alleys) is more promising to maintain the CLM's population for longer time below the control level, in relation to the other densities tested and to monoculture coffee.

\section{CONCLUSIONS}

Coffee plant systems intercropped with rubber trees result in a lower incidence of coffee leaf miners when compared to monoculture coffee, especially in coffee plants near the rubber trees.

The lower incidence of coffee leaf miners near the rubber trees was not related to predation by wasps, but to pest's unfavorable microclimate conditions. Intercropped rubber trees had no protective effect on the leaf miner against rainfall ("umbrella effect"), and rain negatively affected leaf miner occurrence.

\section{ACKNOWLEDGEMENTS}

The Coordenação de Aperfeiçoamento de Pessoal de Nível Superior (CAPES) for granting the scholarship. The State University of Londrina, the Brazilian Coffee Research and Development Consortium (CBP\&D Café)/Embrapa Coffee, and the Agronomic Institute of Paraná (IAPAR) for their support in carrying out the experiment.

\section{REFERENCES}

ALVES, D. S. et al. Selection of active plant extracts against the coffee leaf miner Leucoptera coffeella (Lepidoptera: Lyonetiidae). Revista Brasileira de Plantas Medicinais, Campinas, v. 15, n. 3, p. 352-362, July/Sept. 2013.

AMARAL, D. S. et al. Does vegetational diversification reduce coffee leaf miner Leucoptera coffeella (GuérinMèneville) (Lepidoptera: Lyonetiidae) attack? Neotropical Entomology, Londrina, v. 39, n. 4, p. 543548, July/Aug. 2010.

ANTUNES, F. Z. Fenômenos adversos para a agricultura. Informe Agropecuário, Belo Horizonte, v. 12 , n. 138 , p. $25-30,1986$.

ARAÚJO, A. V. et al. Microclima e crescimento vegetativo do café conilon consorciado com bananeiras. Coffee Science, Lavras, v. 10, n. 2, p. 214-222, Apr/ June. 2015.

ASSIS, G. A. et al. Leaf miner incidence in coffee plants under different drip irrigation regimes and planting densities. Pesquisa Agropecuária Brasileira, Brasília, v. 47, n. 2, p. 157-162, Feb. 2012.

BIANCHI, F. J. J. A.; BOOIJ, C. J. H.; TSCHARNTKE, T. Sustainable pest regulation in agricultural landscapes: a review on landscape composition, biodiversity and natural pest control. Proceedings of the Royal Society of London B: Biological Sciences, London, v. 273, n. 1595, p. 1715-1727, Apr. 2006. 
BICHARA FILHO, C. C. et al. Foraging behavior of the swarm-founding wasp Polybia (Trichothorax) sericea (Hymenoptera, Vespidae): daily resource collection activity and flight capacity. Sociobiology, Feira de Santana, v. 55, n. 3, p. 899-907, Jan. 2010.

CARAMORI, P. H et al. Arborização de cafezais e aspectos climatológicos. In: MATSUMOTO, S. N. (Ed.) Arborização de Cafezais no Brasil. Vitória da Conquista: UESB, 2004. Cap. 1, p. 1-42.

COMPANHIA NACIONAL DE ABASTECIMENTO - CONAB Acompanhamento da safra brasileira de café, Safra 2018. Brasília: CONAB, 2018. 66 p. (v. 5, n. 2). Available on: <https://www.conab.gov.br/infoagro/safras/cafe>. Access in: Aug. 03. 2018.

CONCEIÇÃO, C. H. C.; GUERREIRO-FILHO, O.; GONÇALVES, W. Flutuação populacional do bichomineiro em cultivares de café arábica resistentes à ferrugem. Bragantia, Campinas, v. 64, n. 4, p. 625631, Oct/Dec. 2005

DE LA MORA, A.; LIVINGSTON, G.; PHILPOTT, S. M. Arboreal ant abundance and leaf miner damage in coffee agroecosystems in Mexico. Biotropica, Hoboken, v. 40, n. 6, p. 742-746, May. 2008.

FERNANDES, F. L. et al. Efeitos de variáveis ambientais, irrigação e vespas predadoras sobre Leucoptera coffeella (Guérin-Méneville) (Lepidoptera: Lyonetiidae) no cafeeiro. Neotropical Entomology, Londrina, v. 38, n. 3, p. 410-417, May/June 2009.

FOOD AND AGRICULTURE ORGANIZATION OF THE UNITED NATIONS - FAO Soil map of the world, revised legend, with corrections and updates. World soil resourses report 60, FAO, Rome. Reprinted with updates as technical paper 20, Wageningen: ISRIC, 1997. 140p.

FRAGOSO, D. B. et al. Insecticide use and organophosphate resistance in the coffee leaf miner Leucoptera coffeella (Lepidoptera: Lyonetiidae). Bulletin of Entomological Research, Cambridge, v. 92, n. 3, p. 203-212, June. 2002.

GRAVENA, S. Táticas de manejo integrado do bicho mineiro do cafeeiro Perileucoptera coffeella (GuérinMéneville, 1842): I Dinâmica populacional e inimigos naturais. Anais da Sociedade Entomológica do Brasil, Londrina, v. 12, n. 1, p. 61-71, 1983a.
GRAVENA, S. Táticas de manejo integrado do bichomineiro do cafeeiro Perileucoptera coffeella (GuérinMenèville, 1842). II-Amostragem da praga e de seus inimigos naturais. Anais da Sociedade Entomológica do Brasil, Londrina, v. 12, n. 2, p. 273-281, 1983 b.

GRIMM, A. M. Clima da Região Sul do Brasil. In: CAVAlCANTI, I. F.A. et al. (Eds.) Tempo e Clima no Brasil. São Paulo: Oficina de Textos, 2009. cap. 17, p. 259-275.

GUHARAY, F; MONTERROSO, D.; STAVER, C. El diseño y manejo de la sombra para la supresión de plagas en cafetales de América Central. Agroforestería en las Américas, Costa Rica, v. 8, n. 29, p. 22-29, 2001.

INSTITUTO AGRONÔMICO DO PARANÁ IAPAR. Cartas climáticas do Paraná. Available on: $<$ http://www.iapar.br/modules/conteudo/conteudo. php?conteudo=677>. Access in: 22 Nov. 2014.

INTERNATIONAL COFFEE ORGANIZATION ICO. Historical Data on the Global Coffee Trade. Available on: <http://www.ico.org/new_historical. asp>. Access in: 22 Nov. 2018.

LAWTON, J. H.; MCNEILL, S. Between the devil and the deep blue sea: on the problem of being a herbivore. In: ANDERSON, R. M.; TURNER, B. D.; TAYLOR, L. R. (Eds.) Population dynamics. London: Blackwell Scientific, 1979. p. 223-244.

LIN, B. B. Agroforestry management as an adaptive strategy against potential microclimate extremes in coffee agriculture. Agricultural and Forest Meteorology, New Haven, v. 144, n. 1-2, p. 85-94, May. 2007.

LIN, B. B. The role of agroforestry in reducing water loss through soil evaporation and crop transpiration in coffee agroecosystems. Agricultural and Forest Meteorology, New Haven, v. 150, n. 4, p. 510-518, Apr. 2010.

LIN, B. B. Resilience in agriculture through crop diversification: adaptive management for environmental change. BioScience, Oxford, v. 61, n. 3, p. 183-193, Mar. 2011.

LOMELÍ-FLORES, J. R.; BARRERA, J. F.; BERNAL, J. S. Impacts of weather, shade cover and elevation on coffee leaf miner Leucoptera coffeella (Lepidoptera: Lyonetiidae) population dynamics and natural enemies. Crop Protection, Amsterdam, v. 29, n. 9, p. 10391048, Sept. 2010. 
MEIRELES, D. F.; CARVALHO, J. A.; MORAES, J. C. Avaliação da infestação do bicho-mineiro e do crescimento do cafeeiro submetido a diferentes níveis de déficit hídrico. Ciência e Agrotecnologia, Lavras, v. 25, n. 2, p. 371-374, Mar/Apr. 2001.

MORAIS, H. et al. Caracterização microclimática de cafeeiros cultivados sob malha de sombreamento e a pleno sol. Revista Brasileira de Agrometeorologia, Sete Lagoas, v. 15, n. 2, p. 133-142, 2007.

NESTEL, D.; DICKSCHEN, F.; ALTIERI, M. A. Seasonal and spatial population loads of a tropical insect: the case of the coffee leaf miner in Mexico. Ecological Entomology, London, v. 19, n. 2, p. 159167, Apr/June. 1994.

NEVES, Y. P. et al. Soil moisture and soil fertility of coffee in agroforestry systems. Revista Árvore, Viçosa, v. 31, n. 4, p. 575-588, July/Aug. 2007.

PARRA, J. R. P.; GONÇALVES, W.; PRECETTI, A. A. C. M. Flutuação populacional de parasitos e predadores de Perileucoptera coffeella (Guérin-Meneville, 1842) em três localidades do Estado de São Paulo. Turrialba, San José, v. 3, n. 4, p. 357-364, 1981.

PARTELLI, F. L. et al. Microclimate and development of 'Conilon' coffee intercropped with rubber trees. Pesquisa Agropecuária Brasileira, Brasília, v. 49, n. 11, p. 872-881, Nov. 2014.

PARRA, J. R. P; REIS, P. R. Manejo integrado para as principais pragas da cafeicultura, no Brasil. Revista Visão Agrícola, Piracicaba, n. 12, p. 47-50, Jan/July. 2013.

PEREIRA, A. V.; PEREIRA, E. B. C.; JUNQUEIRA, N. T. V. Seringueira em sistemas agroflorestais. Planaltina: Embrapa-CPAC, 1996. 42p.

PEREIRA, E. J. G. et al. Seasonal mortality factors of the coffee leafminer, Leucoptera coffeella. Bulletin of entomological research, Cambridge, v. 97, n. 4, p. 421-432, Aug. 2007.

PREZOTO, F.; GOBBI, N. Flight range extension in Polistes simillimus Zikán, 1951 (Hymenoptera, Vespidae). Brazilian archives of Biology and Technology, Curitiba, v. 48, n. 6, p. 947-950, Nov. 2005.

REIS, P. R.; SOUZA, J. C. de; ZACARIAS, M. S. Alerta para o bicho-mineiro. Cultivar, Pelotas, v. 8, p. 13-16, Apr. 2006.
REZENDE, M. Q. et al. Extrafloral nectaries of associated trees can enhance natural pest control. Agriculture, Ecosystems \& Environment, Amsterdam, v. 188, p. 198-203, Apr. 2014.

RIBEIRO, B. M.; MAGALHÃES, L. C.; GUEDES, R. N. C. Níveis de resistência a inseticidas organofosforados em populações de Leucoptera coffeella (Guèr-Ménev) (Lepidoptera: Lyonetiidae) de Minas Gerais. Bioscience Journal, Uberlândia, v. 19, n. 2, p. 73-77, May/Aug. 2003.

RICHTER, M. R. Social wasp (Hymenoptera: Vespidae) foraging behavior. Annual Review of Entomology, Guelph, v. 45, n. 1, p. 121-150, 2000.

RIGHI, C. A.; BERNARDES, M. S. The potential for increasing rubber production by matching tapping intensity to leaf area index. Agroforestry System, Dordrecht, v. 72, n. 1, p. 1-13, Jan. 2008.

RIGHI, C. A. et al. Influence of rubber trees on leafminer damage to coffee plants in an agroforestry system. Agroforestry System, Dordrecht, v. 87, n. 6, p. 1351-1362, Nov/Dec. 2013.

SANTOS, G. D. M. et al. Flying capacity of swarmfounding wasp Polybia occidentalis occidentalis Oliver, 1791 (Hymenoptera, Vespidae). Revista Brasileira de Zoociências, Juíz de Fora, v. 2, n. 2, p. 33-39, Dec. 2000.

SANTOS, G. M. M.; BISPO, P. C.; AGUIAR, C. M. L. A. Fluctuations in richness and abundance of social wasps during the dry and wet seasons in three phytophysiognomies at the Tropical Dry Forest of Brazil. Environmental Entomology, Oxford, v. 38, n. 6, p. 1613-1617, Nov/Dec. 2009.

SCALON, J. D. et al. Spatial and temporal dynamics of coffee-leaf-miner and predatory wasps in organic coffee field in formation. Ciência Rural, Santa Maria, v. 41, n. 4, p. 646-652, Apr. 2011.

SILVA, E. M. et al. Tabela de vida para o bicho-mineiro do cafeeiro. In: Simpósio de pesquisa dos cafés do Brasil, 3., 2003, Porto Seguro. Resumos... Brasília: Embrapa Café, 2003. p. 354.

SOUZA, M. M. et al. Nesting of social wasps (Hymenoptera: Vespidae) in a riparian forest of Rio das Mortes in southeastern Brazil. Acta Scientiarum, Biological Sciences, Maringá, v. 36, n. 2, p. 189-196, Apr/June. 2014. 
TEODORO, A.; KLEIN, A. M.; TSCHARNTKE, T. Environmentally mediated coffee pest densities in relation to agroforestry management, using hierarchical partitioning analyses. Agriculture, Ecosystems \& Environment, Amsterdam, v. 125, n. 1-4, p. 120-126, May 2008.

THEODORO, V. C. A.; GUIMARÃES, R. J.; MENDES, A. N. G. Infestation by Leucoptera coffeella and leaf levels of total soluble sugar and protein in organic coffees. Coffee Science, Lavras, v. 9, n. 3, p. 300-311, July/Sept. 2014.

TOZATTI, G.; GRAVENA, S. Natural mortality factors of Perileucoptera coffeella Guérin- Ménèville (Lepidoptera, Lyonetiidae) on coffee in Jaboticabal State of Sao Paulo, Brazil. Científica, v. 16, p. 179187, 1988.

TSCHARNTKE, T. et al. When natural habitat fails to enhance biological pest control - Five hypotheses. Biological Conservation, Amsterdã, v. 204, n. 2, p. 449-458, Dec. 2016.
VEGA, F. E., POSADA, F., INFANTE, F. Coffee insects: Ecology and Control volume II In: PIMENTEL, D. (Ed.). Encyclopedia of pest management. New York: Cornell University, 2007, p. 95-98.

VENZON, M. et al. Toxicity of organic farmingcompatible products to the coffee leaf miner. Pesquisa Agropecuária Brasileira. Brasília, v. 48, n. 3, p. 241248, Mar. 2013.

VENZON, M. et al. The potential of NeemAzal for the control of coffee leaf pests. Crop Protection, United Kingdom, v. 24, n. 3, p. 213-219, 2005.

VOLTAN, R. B. Q.; FAHL, J. I.; CARELLI, M. L. C. Variação na anatomia foliar de cafeeiros submetidos a diferentes intensidades luminosas. Revista Brasileira de Fisiologia Vegetal, Campinas, v. 4, n. 2, p. 99-105, Aug. 1992.

WALlER, J. M.; BIGGER, M.; HILLOCKS, R. J. Coffee pests, diseases and their management. Wallingford: CABI, 2007. 434p. 